\title{
Chaetoglobosins $の{ }^{13}$ C-NMR
}

関田 節子・義平 邦利・名取 信策・宇田川 俊一・坂部 フミ・倉田 浩

S. Sekita, K. Yoshihira, S. Natori, S. Udagawa, F. Sakabe,

H. KuRATA: ${ }^{13} \mathrm{C}-\mathrm{NMR}$ of chaetoglobosins

われわれはこれまでに, Chaetomium globosum 等 から 8 種の chaetoglobosin A, B, C, D, E, F, G, J を単 離し, 構造を明らかにして来た (1 5).

これらの chaetoglobosin を含む cytochalasan 系化 合物は哺乳動物の培養細胞に対して特異な作用を示す. われわれは HeLa 細胞の多核形成 ${ }^{(1,5)}$ をじめとし, 細胞レベルでの運動や形態変化に関する研究を行い, actin の polymerization の阻害効果 ${ }^{(6)}$ などを明らかに して来た.

今回は，乙れらの chaetoglobosin の細胞に 対する 作用と構造の相関々係を明らかにするために，まず ${ }^{13} \mathrm{C}-\mathrm{NMR}$ の測定を行ない, 各炭素の帰属を明らかに することにした。

\section{実験方法及び結果}

chaetoglobosin A, B, C, D, E, F, J を用いて, FX200 (日本電子) $\cdot 50 \mathrm{MHz}$ で測定を行った. 操作方法之 して, COM, OFR, NOE, SEL 等を用いたが, 全ての 炭素の帰属は出来なかった.

そこで, ${ }^{13} \mathrm{C}$ ラベル試薬, ${ }^{13} \mathrm{CH}_{3} \mathrm{COONa}$ と $\mathrm{CH}_{3}$ ${ }^{13} \mathrm{COONa}$ を前駆物質とした培養を行ない, ${ }^{13} \mathrm{C}$ の ベル物質, chaetoglobosin A, B 等を作り, これを用 いて, ${ }^{13} \mathrm{C}-\mathrm{NMR}$ の測定を行ない, 完全な帰属を行っ た.

培養条件は種々の検討の結果, 静置方法では ${ }^{13} \mathrm{C}$ ラ ベルの阼酸の取りこみは行なわれず, PGP 培地での 振璗方法でのみ取りこみが行なわれた.

振燙培養条件の検討の結果, 最適条件は PGP 培地 で振盪，6日目に ${ }^{13} \mathrm{C}$ ラベル試薬を培養液 11 あたり $300 \mathrm{mg}$ を添加, 再び振皹を続け 8 日目に終る培養であ った. 培養後, Myc., Fil. をそれぞれ $\mathrm{CH}_{2} \mathrm{Cl}_{2}$ で抽出

国立衛生試験所(广158 東京都世田谷区上用賀1-18-1) National Institute of Hygienic Sciences (1-18-1, Kamiyoga, Setagaya-ku, Tokyo 158)
した. 培養液 11 あたりの chaetoglobosin A と B の合 計は約 $150 \mathrm{mg}$ であった。 ${ }^{13} \mathrm{C}$ の取り込み率は天然物 に対して 2 倍強 ( ${ }^{13} \mathrm{C}-\mathrm{NMR}$ の测定值) であった.

これらの化合物の ${ }^{13} \mathrm{C}-\mathrm{NMR}$ の測定結果から, chaetoglobosin A, B の炭素の㷌属は Fig. 1 示すように決 められた.

（使用菌株=Chaetomium globosum, 68-SA-2., 振梄 機 $=$ 坂口往復振䔽機, 温度 $=$ 室温 $)$

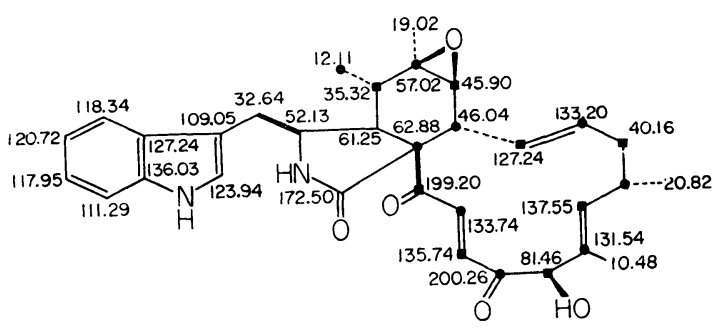

Chaetoglobosin A in DMSO- $\mathrm{d}_{6}$

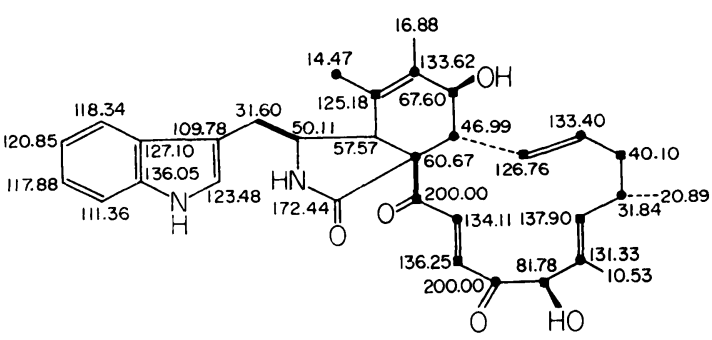

Chaetoglobosin B in DMSO- $\mathrm{d}_{6}$

Fig. $1{ }^{13} \mathrm{C}-\mathrm{MNR}$ chemica! shift and labeling patterns of chaetoglobosin $\mathrm{A}$ and $\mathrm{B}$

- 1-C $\mathrm{C}^{13}$ Sodium acetate

- 2- $\mathrm{C}^{13}$ Sodium acetate

\section{引用文 献}

1) Sekita, S., Yoshihira, K., Natori, S., Udagawa, S., Sakabe, F., Kurata, H., Umeda, M.: Chem. Pharm. Bull., 30, 1609 (1982) 
2) Sekita, S., Yoshihira, K., Natori, S., Kuwano, H.: Chem. Pharm. Bull., 30, 1618 (1982).

3) Sekita, S., Yoshihira, K., Natori, S., Kuwano, H.: Chem. Pharm. Bull., 30, 1629 (1982).

4) Sekita, S., Yoshihira, K., Natori, S., Kuwano, H.: Tetrahedron Letters, 1977, 2771
5) Udagawa, S., Muroi, T., Kurata, H., Sekita, S., Yoshihira, K., Natori, S., Umeda, M: Can. J. Mycrobiol., 25, 170 (1979).

6) Yahara, I., Harada, F., Sekita, S., Yoshihira, K., Natori, S.: J. Cell. Biol., 92, 69 (1982). 